\title{
Individual Reproductive Success of Largemouth Bass and Smallmouth Bass Subjected to Different Components of Competitive Angling Events
}

\author{
Michael J. Siepker, ${ }^{1} *$ Steven J. Cooke, ${ }^{2}$ David H. Wahl, and David P. Philipp \\ Illinois Natural History Survey, Section for Aquatic Ecology and Conservation, 1816 South Oak Street, \\ Champaign, Illinois 61820, USA; and Department of Natural Resources and Environmental Sciences, \\ University of Illinois, W-503 Turner Hall, Urbana, Illinois 61801, USA
}

\begin{abstract}
The continued popularity of angling for largemouth bass Micropterus salmoides and smallmouth bass $M$. dolomieu has led to concerns about the effects it may have on fish populations, including the realized fitness of individuals. Although catch-and-release angling and its effects on nest abandonment have been well documented, very little research has examined the effect that competitive angling practices may have on nest abandonment. We subjected nest-guarding male largemouth bass in one lake and smallmouth bass in four lakes to various competitive angling practices (i.e., livewell retention, release after displacement from the nest, and a combination of these practices) and assessed subsequent nest abandonment. We also examined the importance of nest predation on the nest abandonment decisions of male bass by protecting some of the nests from predation after the angling event. Nest abandonment by largemouth bass was affected by angling treatment, the water depth at the nest site, and brood size but was not affected by male size. Angling treatment and lake influenced abandonment by smallmouth bass guarding eggs, whereas angling treatment, lake, and the presence of a protective nest cover influenced nest abandonment by smallmouth bass guarding fry. The only factor that influenced abandonment for both species and all stages was angling treatment, with abandonment being highest for all treatments that involved prolonged removal and displacement (i.e., the complete tournament simulation). These findings could be important to bass populations if year-class size is related to the number of successful nests. The effects of angling, both catch and release and competitive, on individual nesting success in largemouth bass and smallmouth bass are now well understood, although additional work is needed to determine whether disruption of nesting at the individual level translates to population-level effects.
\end{abstract}

The complex reproductive strategy of largemouth bass Micropterus salmoides and smallmouth bass $M$. dolomieu (collectively referred to as black bass), combined with continued interest in fishing for these species, has contributed to concerns over the long-term effects that angling is having on black bass populations (Schramm et al. 1991a; Wilde et al. 1998; Siepker et al. 2007). When spring water temperatures increase to above $14^{\circ} \mathrm{C}$, male black bass prepare shallow, saucershaped nests before courting and spawning with females (Kramer and Smith 1962; Annett et al. 1996). After depositing the eggs, the females leave the nest, whereas the male remains to provide sole parental care for the offspring (Ridgway 1988). The

\footnotetext{
* Corresponding author: Mike.Siepker@mdc.mo.gov

${ }^{1}$ Present address: Missouri Department of Conservation, Resource Science Division, 551 Joe Jones Boulevard, West Plains, Missouri 65775, USA

${ }^{2}$ Present address: Fish Ecology and Conservation Physiology Laboratory, Department of Biology and Institute of Environmental Science, Carleton University, 1125 Colonel By Drive, Ottawa, Ontario K1S 5B6, Canada
}

Received December 11, 2007; accepted March 2, 2009 Published online May 28, 2009 male fans the eggs to keep them free of silt and in contact with freshwater, and he guards his offspring against brood predation (Kramer and Smith 1962; Hunt et al. 2002). Parental care, which is vital to brood success, extends for several weeks after the eggs hatch (Neves 1975; Annett et al. 1996; Cooke et al. 2006), lasting until the offspring can function independently. It is during this period of parental care that removal of the male's protection by anglers often results in nest predators consuming the offspring (Kieffer et al. 1995; Steinhart et al. 2004). The amount of brood predation increases as the time the male is absent from the nest increases (Philipp et al. 1997); brood reductions often lead to an increase in the likelihood of nest abandonment (Suski et al. 2003b; Hanson et al. 2007). Even those fish that do not abandon nests after angling are exposed to sublethal stressors (Kieffer et al. 1995; Ostrand et al. 2004; Hanson et al. 2008) and provide care with less vigor than if they had not been angled (Cooke et al. 2000). Because they are aggressively guarding their brood against potential predators (Cooke et al. 2002a), male bass are quite vulnerable to intense spring angling pressure (Jennings 1997; Philipp et al. 1997; Suski and Philipp 2004). Consistently high 
spring angling effort, a result of continued interest in black bass angling (Shupp 1979; Duttweiler 1985; Schramm et al. 1991b; Kerr and Kamke 2003), could negatively affect the reproductive success of individual black bass.

Different angling practices and handling methods may affect black bass in different ways. Bass that are angled and immediately released during catch-andrelease angling experience a suite of physiological alterations that include changes in blood and muscle biochemistry (Gustaveson et al. 1991; Kieffer et al. 1995; Suski et al. 2004; Hanson et al. 2008) and cardiovascular disturbances (Schreer et al. 2001; Cooke et al. 2004). Catch-and-release angling of nesting male black bass also negatively affects individual reproductive success by increasing nest abandonment rates (Philipp et al. 1997; Suski et al. 2003b; Hanson et al. 2007, 2008). The time required for fish to return to their nest after being caught and immediately released has been previously linked to abandonment rates (Philipp et al. 1997; Hanson et al. 2007), suggesting that the potential for angling to negatively affect reproductive activities of black bass is increased when fish are captured and held for extended time periods such as during competitive angling events. Competitively angled bass are usually held in livewells after capture until transported some distance to a central location (Stang et al. 1996; Bunt et al. 2002; Wilde 2003), where they are weighed and released. During this holding and transport period, fish are subjected to varying levels of additional stressors (Cooke et al. 2002b; Suski et al. 2003a, 2004, 2005). Initial work has shown greater rates of nest abandonment by smallmouth bass subjected to competitive angling practices relative to those subjected to catch-and-release practices (Hanson et al. 2008). It is, however, not known how specific components of competitive angling practices affect individual reproductive success of black bass.

Factors other than angling also influence nest abandonment by parental male black bass. Important differences between the reproductive behaviors of largemouth and smallmouth bass influence their nest abandonment decisions. Largemouth bass tend to spawn on medium-sized substrate (i.e., sand or gravel; Annett et al. 1996; Hunt et al. 2002) or on vegetation in protected littoral areas (Kramer and Smith 1962), whereas smallmouth bass usually select littoral areas that are more exposed and consist of larger gravel or cobble substrate for spawning (Neves 1975; Bozek et al. 2002). These differences in spawning habitats could result in broods being subjected to differing levels of predation, wave action, or both (Steinhart et al. 2005), thereby resulting in different rates of nest abandon- ment. Additionally, parental investment theory predicts that as offspring age increases, risk-taking and energetic investment by the parent should also increase (Sargent and Gross 1986). This pattern in the intensity of parental care has been observed for black bass, with parental defense behaviors generally peaking at the wriggler stage and decreasing by the fry swim-up stage (Ridgway 1988; Cooke et al. 2002a). Finally, factors such as brood size, parental male size, nest depth, and lake-specific variables may all influence observed nest abandonment by black bass.

To understand how competitive angling practices affect reproductive success in black bass, we conducted a field study with the objective of comparing nest abandonment by parental male black bass subjected to various components of competitive angling (i.e., the time removed from the nest, distance released from the nest, and a combination of the two). Our second objective was to determine the influence of brood predation on the parental male's decision to abandon his nest by using covers made from hardware cloth to protect a portion of the nests from brood predation. To understand the underlying mechanisms driving nest abandonment in black bass, we also assessed how the lake, male size, nest depth, and brood size influenced abandonment. We conducted our assessment on both largemouth bass and smallmouth bass guarding eggs and smallmouth bass guarding fry because speciesspecific differences as well as developmental stage of the offspring also influence nest abandonment.

\section{Methods}

Largemouth bass nests were located by means of snorkel surveys in Lake Opinicon, southeastern Ontario, whereas smallmouth bass nests were located in Lake Opinicon, Sand Lake, Charleston Lake, and Wolfe Lake. Lakes were selected based on the abundance of study fish inhabiting the waters, and all lakes contained a variety of known brood predators (e.g., bluegill Lepomis macrochirus, pumpkinseed $L$. gibbosus, rock bass Ambloplites rupestris, black crappie Pomoxis nigromaculatus, and yellow perch Perca flavescens). Nests were marked underwater with a numbered polyvinyl chloride tag, and their locations were mapped on a plastic slate. Snorkelers also recorded nest depth, brood size (a ranking system from 1 to 5 , with 1 representing a nest with few eggs and 5 representing a nest containing a large number of eggs; Kubacki 1992), and developmental stage of the offspring (i.e., egg or fry in nest; Kramer and Smith 1962; Kieffer et al. 1995). Study groups consisting of male largemouth bass $(360 \pm 4 \mathrm{~mm}$ total length [TL], mean \pm SE) guarding eggs and male smallmouth bass guarding either eggs $(381 \pm 4 \mathrm{~mm})$ or fry $(386 \pm 5$ 
$\mathrm{mm})$ were angled off nests from 23 May to 17 June 2002. After fish were successfully hooked and landed, they were measured (TL) and given a fin clip for later identification on the nest. A completely randomized design with nest abandonment as the binary response variable was used to assign males to one of the following treatments:

(1) Control: males were only exposed to measurement of nest data. Male sizes were estimated underwater by the snorkeler, and no angling treatment was applied to the fish.

(2) Catch and Release: males were removed from their nests by hook-and-line angling. Anglers used a Texas-rigged, $10-\mathrm{cm}$ plastic worm and cast past the nest before working the bait into the nest. After anglers sensed a strike, they set the hook and quickly landed the fish $(\sim 15 \mathrm{~s})$. Fish were then subjected to a 120 -s period of air exposure (Cooke et al. 2002b), a length of time typically required to remove the hook and measure the fish's TL, before releasing the individual within $10 \mathrm{~m}$ of his nest.

(3) Distance: males were angled as above and subjected to a 120 -s period of air exposure during hook removal and measuring, and during that time each fish was moved $1 \mathrm{~km}$ from the nest site and released. Fish are often transported greater distances during actual competitive angling events (see Stang et al. 1996; Bunt et al. 2002; Wilde 2003); we chose displacement of $1 \mathrm{~km}$ for this study as a conservative but still common distance for tournaments in small lakes.

(4) Time: males were angled as above, subjected to $120 \mathrm{~s}$ of air exposure while the hook was removed and a TL measurement taken, and placed in a recirculating livewell (41 $\mathrm{L}$ with intermittent flow through; i.e., a timer provided fresh lake water for 1 min every $6 \mathrm{~min}$ ). Fish densities never exceeded five fish per livewell. After $2 \mathrm{~h}$, each fish was returned to the nest site and released within $10 \mathrm{~m}$ of the nest.

(5) Time + Distance: males were angled, subjected to a 120-s period of air exposure, and placed in a recirculating livewell as described previously. After $2 \mathrm{~h}$ of confinement, the parental male was moved $1 \mathrm{~km}$ from the nest site and released.

Of the 20 nests receiving each treatment, half of the nests were protected with nest covers modified from the design by Bain and Helfrich (1983). Nest covers were constructed from hardware cloth (mesh size, 12.7 $\mathrm{mm} ; 19$ gauge) bent at $90^{\circ}$ on all sides to form an openended box $(50 \times 50 \times 5 \mathrm{~cm})$. Immediately after the capture of the male (or during nest guarding for control males), covers were pressed into the substrate or weighted on the corners with rocks to prevent nest predator access to offspring. Divers were careful to ensure that placement of the covers did not disturb the nest or generate silt deposits. Nest abandonment was assessed as a binary response variable (nest guarding versus nest abandonment) for each male at $24 \mathrm{~h}$ postangling.

For each study group, we fit male abandonment with logistic models to explain relationships to lake, angling treatment, protective nest cover, male TL, nest depth, and brood size. We used Akaike's information criterion corrected for small-sample bias (AIC ${ }_{c}$; SAS Institute 1999; Burnham and Anderson 2002) for each model to assess the importance of all factors and their interactions in the model. We chose the best model to be the most parsimonious model among candidate models with an $\mathrm{AIC}_{c}$ difference less than 2 and containing only significant model parameters (Burnham and Anderson 2002). Model fit was verified using Hosmer-Lemeshow goodness-of-fit tests. We then used Wald chisquare $\left(\chi^{2}\right)$ statistics to test contrasts, and the estimated probability of abandonment was calculated by multiplying the variable coefficient from the logistic regression by the value of the variable and adding that value to the estimate on the logit scale. For all statistical comparisons, the significance level $\alpha$ was set a priori at 0.05 .

\section{Results}

A total of 302 nests were surveyed across all study groups, with similar sample sizes obtained for each treatment level (Figure 1). Nest abandonment by parental male largemouth bass guarding eggs was significantly influenced by angling treatment (Wald $\chi^{2}$ $=10.71$, df $=4, P=0.03$; Table 1); however, only largemouth bass subjected to the Time + Distance treatment abandoned their nests significantly more often (Wald $\chi^{2}=4.86$, $\mathrm{df}=1, P=0.03$ ) in comparison with controls. The predicted probability of a nest being abandoned by the parental male increased across angling treatments from controls $(0.11)$ to Time + Distance (0.44) treatments. Among largemouth bass nests, brood size also significantly influenced nest abandonment by parental males (Wald $\chi^{2}=4.41$, df $=$ $1, P=0.04)$. When brood size score increased from 2 to 5 , the probability of abandonment was reduced from 0.24 to 0.04 . Finally, nest depth significantly (Wald $\chi^{2}$ $=7.16, \mathrm{df}=1, P<0.01)$ influenced nest abandonment by parental male largemouth bass. When nest depths increased from 0.5 to $1.5 \mathrm{~m}$, the probability of abandonment was reduced from 0.28 to 0.04 .

The likelihood that smallmouth bass guarding eggs abandoned their nests varied significantly between 


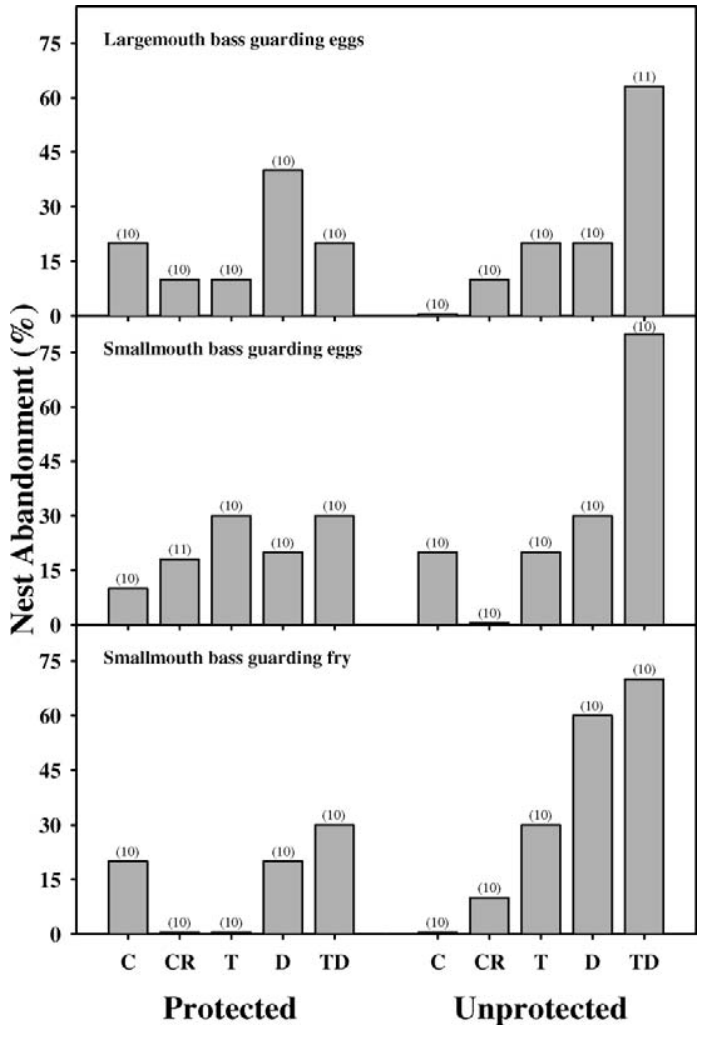

FiguRE 1.-Rates of nest abandonment (\%; at $24 \mathrm{~h}$ postangling) by egg-guarding largemouth bass and egg- or fry-guarding smallmouth bass in the Control group (C) or in groups subjected to Catch-and-Release (CR), Time (T), Distance (D), or Time + Distance (TD) components of recreational angling (see Methods) in southeastern Ontario lakes. Nests were either protected (with a screen cover) or unprotected from brood predation. Sample sizes for each treatment combination are shown in parentheses.

lakes (Wald $\chi^{2}=9.60, \mathrm{df}=1, P<0.01$; Table 1 ). The predicted probability that undisturbed smallmouth bass guarding eggs would abandon their nests was higher in Charleston Lake (0.23) than in Lake Opinicon (0.03). Angling treatments also varied by lake, with the probability of abandonment in the Time + Distance treatment increasing from 0.31 for fish in Lake Opinicon to 0.79 for fish in Charleston Lake. Nest abandonment also varied (Wald $\chi^{2}=14.21, \mathrm{df}=4, P$ $<0.01$ ) across angling treatments applied. Smallmouth bass subjected to the Time + Distance angling treatment abandoned nests significantly more often (Wald $\chi^{2}=8.71, \mathrm{df}=1, P<0.01$ ) than those left to guard their offspring undisturbed (controls). Smallmouth bass subjected to other angling treatments, however, did not abandon their nests significantly more often $(P$ range $=0.41-0.56)$ in comparison with smallmouth bass controls.

Abandonment of nests by smallmouth bass guarding fry was significantly influenced by lake (Wald $\chi^{2}=$ 6.37 , $\mathrm{df}=2, P=0.04$ ), presence of a protective nest cover (Wald $\chi^{2}=6.42$, $\mathrm{df}=1, P=0.01$ ), and angling treatment (Wald $\chi^{2}=14.45, \mathrm{df}=4, P<0.01$; Table 1). Relative to Control fish, smallmouth bass receiving either Catch-and-Release (Wald $\chi^{2}=0.35, \mathrm{df}=1, P=$ 0.55 ) or Time (Wald $\chi^{2}=0.28$, df $=1, P=0.59$ ) angling treatments had similar levels of nest abandonment. Fry-guarding smallmouth bass that received a Distance (Wald $\chi^{2}=4.50, \mathrm{df}=1, P=0.03$ ) or a Time + Distance (Wald $\chi^{2}=7.45, \mathrm{df}=1, P<0.01$ ) angling treatment abandoned their nests significantly more often than controls. Predicted probability of nest abandonment by control smallmouth bass varied from 0.01 in Wolfe Lake to 0.11 and 0.15 in Charleston and Sand lakes, respectively. Predicted probabilities of abandonment were also lowest for Wolfe Lake in the Distance (0.06) and Time + Distance (0.11) treatment groups, whereas Sand Lake had higher predicted probabilities of nest abandonment (Distance: 0.53, Time + Distance: 0.67 ) compared with those in Wolfe and Charleston lakes.

\section{Discussion}

We observed greater rates of nest abandonment for largemouth bass and smallmouth bass subjected to simulated competitive angling practices than was previously observed for fish that were caught and released (Philipp et al. 1997; Suski et al. 2003b; Hanson et al. 2007) or electrofished (Siepker et al. 2006) from their nests. The competitive angling practice that removed fish the longest (i.e., Time + Distance) resulted in the highest levels of nest abandonment across all study groups, whereas those that allowed fish to stay at the nest (controls) or allowed fish to quickly return to their nest (Catch and Release) after angling resulted in little or no nest abandonment. Black bass subjected to the Time component (held in livewells for $2 \mathrm{~h}$ and released at the nest) abandoned their nests less often than did bass receiving the Distance treatments even though fish were only moved $1 \mathrm{~km}$ from their nest sites, a conservative estimate of the effect of displacement on individual nesting success. It is likely that competitively angled black bass are displaced much greater distances in actual angling events (see Wilde 2003). As the distances black bass are displaced increase, we expect abandonment rates to increase as well for these fish. Fish in the Distance treatments (released $1 \mathrm{~km}$ from their nests) probably had less energy available to begin parental care activities upon their return, whereas 
TABLE 1.-Logistic regression models for predicting nest abandonment by largemouth bass and smallmouth bass, determined by Akaike's information criterion (AIC). Separate models were evaluated for largemouth bass guarding eggs, smallmouth bass guarding eggs, and smallmouth bass guarding fry. The $\mathrm{AIC}_{c}$ is the AIC corrected for small-sample bias; $\Delta \mathrm{AIC}_{c}$ is the difference between the $\mathrm{AIC}_{c}$ of the candidate model and that of the model exhibiting the lowest $\mathrm{AIC}_{c}$. Models selected for prediction (shown in bold text) had $\Delta \mathrm{AIC}_{c}$ values less than 2 and contained model parameters that were significant in the logistic regression.

\begin{tabular}{|c|c|c|c|}
\hline Model and parameters & AIC & $\mathrm{AIC}_{c}$ & $\Delta \mathrm{AIC}_{c}$ \\
\hline \multicolumn{4}{|l|}{ Largemouth bass guarding eggs } \\
\hline Nest depth, Male total length (TL), Egg score, Treatment & 92.36 & 93.91 & 0.00 \\
\hline Nest depth, Egg score, Treatment & 92.87 & 94.06 & 0.15 \\
\hline Nest depth, Male TL, Egg score, Treatment, Cover & 94.27 & 96.23 & 2.32 \\
\hline Nest depth, Treatment & 95.70 & 96.58 & 2.67 \\
\hline Nest depth, Male TL, Egg score, Treatment, Cover, Treatment $\times$ Cover & 95.73 & 99.86 & 5.95 \\
\hline Egg score, Treatment & 100.89 & 101.77 & 7.86 \\
\hline Treatment & 105.19 & 105.82 & 11.90 \\
\hline \multicolumn{4}{|l|}{ Smallmouth bass guarding eggs } \\
\hline Nest depth, Lake, Treatment & 100.26 & 101.47 & 0.00 \\
\hline Nest depth, Egg score, Lake, Treatment & 100.30 & 101.88 & 0.41 \\
\hline Lake, Treatment & 101.16 & 102.06 & 0.59 \\
\hline Nest depth, Male TL, Egg score, Lake, Treatment & 101.69 & 103.69 & 2.21 \\
\hline Nest depth, Male TL, Egg score, Lake, Treatment, Cover & 103.11 & 105.58 & 4.11 \\
\hline Nest depth, Male TL, Egg score, Lake, Treatment, Cover, Treatment $\times$ Cover & 104.30 & 109.25 & 7.77 \\
\hline Lake & 110.84 & 110.97 & 9.49 \\
\hline Treatment & 112.02 & 112.66 & 11.19 \\
\hline \multicolumn{4}{|l|}{ Smallmouth bass guarding fry } \\
\hline Egg score, Lake, Treatment, Cover & 89.93 & 91.93 & 0.00 \\
\hline Lake, Treatment, Cover & 90.76 & 92.35 & 0.41 \\
\hline Male TL, Egg score, Lake, Treatment, Cover & 90.40 & 92.87 & 0.94 \\
\hline Nest depth, Male TL, Egg score, Lake, Treatment, Cover & 91.12 & 94.12 & 2.18 \\
\hline Nest depth, Male TL, Egg score, Lake, Treatment, Cover, Treatment $\times$ Cover & 91.29 & 97.01 & 5.07 \\
\hline Lake, Treatment & 95.99 & 97.21 & 5.28 \\
\hline Treatment, Cover & 97.66 & 98.56 & 6.63 \\
\hline Lake, Cover & 101.98 & 102.40 & 10.47 \\
\hline
\end{tabular}

fish that were held in livewells and released at the nest should have partially recovered from angling stressors by the time of their release (Cooke et al. 2000, 2002b; Suski et al. 2004), allowing them to more effectively resume energetically costly parental care activities (Gillooly and Baylis 1999; Mackereth et al. 1999).

When we protected nests from brood predation, nest abandonment rates decreased in some treatment groups by up to $50 \%$ (Figure 1). Protective covers significantly reduced nest abandonment when smallmouth bass were guarding fry in their nests. We suspect that fry in the nest were more visible to potential predators and were easier to consume, making additional protection from predation important. In our study and the study by Suski et al. (2003b), the decision to abandon the nest appears to be driven by the level of nest predation that occurs in the absence of the male. Nests with protective screen covers had consistent brood sizes and only slightly increased levels of nest abandonment by parental males. Fish that took more time to return to their unprotected nests after displacement probably had more brood predation occur, resulting in devalued broods and increased levels of nest abandonment compared with fish that were released at their nests.

Additional biotic and abiotic characteristics also help to explain nest abandonment in black bass. Largemouth bass nests that were abandoned by parental males had smaller initial brood sizes than those that were reoccupied. Nests with small initial brood sizes could be quickly consumed by predators in the absence of the male, whereas nests with large broods would require longer periods of predation before they are consumed, increasing the likelihood that parental males could return to the nest, thereby preventing total nest predation. Largemouth bass nests located in shallower water also had higher probabilities of abandonment than did deeper nests, probably reflecting increased brood loss due to higher levels of nest predators occupying shallow habitats (Neves 1975; Hunt et al. 2002). In both smallmouth bass study groups, lake was a significant variable in our final model. Nest abandonment decisions were probably influenced by some abiotic or biotic variable associated with individual lakes. Because we did not measure any lake-associated variables, we cannot evaluate their influence on nest abandonment. Clearly, variation in nest abandonment across lakes does exist and may be related to differences in variables such as nest predator populations, habitat, substrate, or lake morphology. Additional inquiry into causal factors of lake-specific 
differences in nest abandonment would provide valuable information for future modeling of black bass recruitment.

Decreased individual reproductive success for parental male black bass subjected to simulated competitive angling practices has been demonstrated in this study and for fish caught and released in other studies (Kieffer et al. 1995; Philipp et al. 1997; Suski et al. 2003b; Hanson et al. 2008). Combined, these studies provide evidence that angling during the reproductive period does indeed reduce individual nest success, but much work needs to be done before we fully understand population-level effects (Cooke and Schramm 2007; Siepker et al. 2007). Ridgway and Shuter (1997) found that as the daily probability of capture during the nesting period of black bass modeled in a catch-and-keep fishery increased, the simulated relative abundance of age- 0 fish present decreased. Because competitive events could be considered "catch-and-keep for some period," we might expect a similar effect on age-0 fish in a system with high tournament pressure. One limitation of the Ridgway and Shuter (1997) model is that it does not consider potential compensatory mechanisms at the larval stage. If losses that occur during the egg or larval stages are compensated for by increased survival of offspring at later stages of development, then egg mortality may not be as critical to recruitment of a particular year-class (see Walters and Martell 2004). To clarify these issues, we suggest that future research (1) acknowledge that males do abandon their nests when angled and (2) focus on determining whether this abandonment affects black bass populations or whether these effects are dampened by either other biotic and abiotic processes during the spawning period or some later compensatory mechanisms.

Overall, average fishing mortality rates for largemouth bass appear to have steadily decreased since the 1990s (Allen et al. 2008), probably as a result of increased rates of voluntary release (Noble 2002; Myers et al. 2008). These trends suggest that fishing mortality will continue to decrease or remain low in many lakes, resulting in improved survival and increased abundance of catchable-sized black bass. These reductions in fishing mortality combined with advances in fish handling methods (see Cooke and Schramm 2007) by catch-and-release and competitive anglers should help to maintain or improve bass populations. If, however, fisheries managers feel that competitive angling events might be reducing black bass populations in their waters, alternative formats for these events during the black bass reproductive period might be applicable. Reducing the time for which fish are away from their nests could be achieved by omitting the weigh-in process and replacing it with measuring the fish (either weight or length) right after capture and then immediately releasing the fish. Allowing angling, including competitive events, during the reproductive period on only a portion of the lake would help to protect a segment of the reproductive population from both catch-and-release and competitive angling practices (Suski et al. 2002). This approach could fulfill the desires of both anglers and fishery managers by providing angling opportunities throughout the season while concurrently affording protection to a segment of reproductively active fish. Although substantial work has been done on the effects of angling (catch and release and competitive) on individual nesting success of black bass, it is still unclear how individual abandonment relates to changes at the population level. Increased survival of black bass resulting from high rates of voluntary release combined with knowledge gained from further research into population-level effects of angling nesting bass will ensure that largemouth bass and smallmouth bass populations remain at or above levels that are acceptable to anglers.

\section{Acknowledgments}

Numerous individuals contributed to the collection of these data; in particular, we thank J. Degner, A. Readel, M. Bartkowska, B. Barthel, D. Barthel, J. Svec, J. Claussen, J. Epifanio, R. Holthusen, F. Phelan, P. Weatherhead, J. Cooke, and D. Weber. M. Wallendorf (Missouri Department of Conservation) and M. Muyot (University of Illinois Statistical Office) provided valuable biometric consultation. This study was conducted at the Queen's University Biological Station, and we thank F. Phelan, F. Connor, and R. Robertson for facilitating this research. The Ontario Ministry of Natural Resources kindly provided necessary permits. Financial support was provided by the University of Illinois, Illinois Natural History Survey, Illinois Department of Natural Resources, and the Natural Sciences and Engineering Research Council of Canada. The Ron Ward Memorial Bass Research Scholarship from the Champaign-Urbana Bass Club awarded to M.J.S. provided additional support. K. Ostrand, J. Parkos III, and the Aquatic Ecology Discussion Group of the Kaskaskia Biological Station provided valuable comment and insight. M. Allen provided constructive comments that helped to improve the quality of this manuscript.

\section{References}

Allen, M. S., C. J. Walters, and R. Myers. 2008. Temporal trends in largemouth bass mortality, with fishery 
implications. North American Journal of Fisheries Management 28:418-427.

Annett, C., J. Hunt, and E. D. Dibble. 1996. The compleat bass: habitat use patterns of all stages of the life cycle of largemouth bass. Pages 306-314 in L. E. Miranda and D. R. DeVries, editors. Multidimensional approaches to reservoir fisheries management. American Fisheries Society, Symposium 16, Bethesda, Maryland.

Bain, M. B., and L. A. Helfrich. 1983. Role of male parental care in survival of larval bluegills. Transactions of the American Fisheries Society 112:47-52.

Bozek, M. A., P. H. Short, C. J. Edwards, M. J. Jennings, and S. P. Newman. 2002. Habitat selection of nesting smallmouth bass Micropterus dolomieu in two north temperate lakes. Pages 135-148 in D. P. Philipp and M. S. Ridgway, editors. Black bass: ecology, conservation, and management. American Fisheries Society, Symposium 31, Bethesda, Maryland.

Bunt, C. M., S. J. Cooke, and D. P. Philipp. 2002. Mobility of riverine smallmouth bass related to tournament displacement and seasonal habitat use. Pages 545-552 in D. P. Philipp and M. S. Ridgway, editors. Black bass: ecology, conservation, and management. American Fisheries Society, Symposium 31, Bethesda, Maryland.

Burnham, K. P., and D. R. Anderson. 2002. Model selection and multi-model inference: a practical informationtheoretic approach, 2nd edition. Springer-Verlag, New York.

Cooke, S. J., C. M. Bunt, K. G. Ostrand, D. P. Philipp, and D. H. Wahl. 2004. Angling-induced cardiac disturbance of free-swimming largemouth bass (Micropterus salmoides) monitored with heart rate telemetry. Journal of Applied Ichthyology 20:28-36.

Cooke, S. J., D. P. Philipp, J. F. Schreer, and R. S. McKinley. 2000. Locomotory impairment of nesting male largemouth bass following catch-and-release angling. North American Journal of Fisheries Management 20:968-977.

Cooke, S. J., D. P. Philipp, D. H. Wahl, and P. J. Weatherhead. 2006. Parental care energetics of six syntopic centrarchid fishes. Oecologia 148:235-249.

Cooke, S. J., D. P. Philipp, and P. J. Weatherhead. 2002a. Parental care patterns and energetics of smallmouth bass, Micropterus dolomieu, and largemouth bass, M. salmoides, monitored with activity transmitters. Canadian Journal of Zoology 80:756-770.

Cooke, S. J., and H. L. Schramm, Jr. 2007. Catch-and-release science and its application to conservation and management of recreational fisheries. Fisheries Management and Ecology 14:73-79.

Cooke, S. J., J. F. Schreer, D. H. Wahl, and D. P. Philipp. 2002b. Physiological impacts of catch-and-release angling practices on largemouth bass and smallmouth bass. Pages 489-512 in D. P. Philipp and M. S. Ridgway, editors. Black bass: ecology, conservation, and management. American Fisheries Society, Symposium 31, Bethesda, Maryland.

Duttweiler, M. W. 1985. Status of competitive fishing in the United States: trends and state fisheries policies. Fisheries 10(5):5-7.

Gillooly, J. F., and J. R. Baylis. 1999. Reproductive success and the energetic cost of parental care in male smallmouth bass. Journal of Fish Biology 54:573-584.
Gustaveson, A. W., R. S. Wydoski, and G. A. Wedemeyer. 1991. Physiological response of largemouth bass to angling stress. Transactions of the American Fisheries Society 120:629-636.

Hanson, K. C., S. J. Cooke, C. D. Suski, and D. P. Philipp. 2007. Effects of different angling practices on postrelease behaviour of nest guarding male black bass, Micropterus spp. Fisheries Management and Ecology 14:141-148.

Hanson, K. C., M. Gravel, T. Redpath, S. J. Cooke, and M. J. Siepker. 2008. Latitudinal variation in physiological and behavioral responses of nest guarding smallmouth bass to common recreational angling practices. Transactions of the American Fisheries Society 137:1558-1566.

Hunt, J., N. Bacheler, D. Wilson, E. Videan, and C. A. Annett. 2002. Enhancing largemouth bass spawning: behavioral and habitat considerations. Pages 277-290 in D. P. Philipp and M. S. Ridgway, editors. Black bass: ecology, conservation, and management. American Fisheries Society, Symposium 31, Bethesda, Maryland.

Jennings, M. J. 1997. Centrarchid reproductive behavior: implications for management. North American Journal of Fisheries Management 17:493-495.

Kerr, S. J., and K. K. Kamke. 2003. Competitive fishing in freshwaters of North America. Fisheries 28(3):26-31.

Kieffer, J. D., M. R. Kubacki, F. J. S. Phelan, D. P. Philipp, and B. L. Tufts. 1995. Effects of catch-and-release angling on nesting male smallmouth bass. Transactions of the American Fisheries Society 124:70-76.

Kramer, R. H., and L. L. Smith. 1962. Formation of year classes in largemouth bass. Transactions of the American Fisheries Society 91:29-41.

Kubacki, M. R. 1992. The effectiveness of a closed season for protecting nesting largemouth and smallmouth bass in southern Ontario. Master's thesis. University of Illinois, Urbana.

Mackereth, R. W., D. L. G. Noakes, and M. S. Ridgway. 1999. Size-based variation in somatic energy reserves and parental expenditure by male smallmouth bass, Micropterus dolomieu. Environmental Biology of Fishes 56:263-275.

Myers, R., J. Taylor, M. Allen, and T. F. Bonvechio. 2008. Temporal trends in voluntary release of largemouth bass. North American Journal of Fisheries Management 28:428-433.

Neves, R. J. 1975. Factors affecting fry production of smallmouth bass (Micropterus dolomieu) in South Branch Lake, Maine. Transactions of the American Fisheries Society 104:83-87.

Noble, R. L. 2002. Reflections on 25 years of progress in black bass management. Pages 419-431 in D. P. Philipp and M. S. Ridgway, editors. Black bass: ecology, conservation, and management. American Fisheries Society, Symposium 31, Bethesda, Maryland.

Ostrand, K. G., S. J. Cooke, and D. H. Wahl. 2004. Effects of stress on largemouth bass reproduction. North American Journal of Fisheries Management 24:1038-1045.

Philipp, D. P., C. A. Toline, M. F. Kubacki, D. B. F. Philipp, and F. J. S. Phelan. 1997. The impact of catch-andrelease angling on the reproductive success of smallmouth bass and largemouth bass. North American Journal of Fisheries Management 17:557-567. 
Ridgway, M. S. 1988. Developmental stage of offspring and brood defense in smallmouth bass (Micropterus dolomieu). Canadian Journal of Zoology 66:1722-1728.

Ridgway, M. S., and B. J. Shuter. 1997. Predicting the effects of angling for nesting male smallmouth bass on production of age- 0 fish with an individual-based model. North American Journal of Fisheries Management 17:568-580.

Sargent, R. C., and M. R. Gross. 1986. Williams' principle: an explanation of parental care in teleost fishes. Page 275293 in T. J. Pitcher, editor. The behavior of teleost fishes. Johns Hopkins University Press, Baltimore, Maryland.

SAS Institute. 1999. SAS version 8.1. SAS Institute, Cary, North Carolina.

Schramm, H. L., Jr., M. L. Armstrong, A. J. Fedler, N. A. Funicelli, D. M. Green, J. L. Hahn, D. P. Lee, R. E. Manns, Jr., S. P. Quinn, and S. J. Waters. 1991a. Sociological, economic, and biological aspects of competitive fishing. Fisheries 16(3):13-21.

Schramm, H. L., Jr., M. L. Armstrong, N. A. Funicelli, D. M. Green, D. P. Lee, R. E. Manns, Jr., B. D. Taubert, and S. J. Waters. 1991b. The status of competitive sport fishing in North America. Fisheries 16(3):4-13.

Schreer, J. F., S. J. Cooke, and R. S. McKinley. 2001. Cardiac response to variable forced exercise at different temperatures-an angling simulation for smallmouth bass. Transactions of the American Fisheries Society 130:783-795.

Shupp, B. D. 1979. Status of bass fishing tournaments in the United States. Fisheries 4(6):11-19.

Siepker, M. J., K. G. Ostrand, S. J. Cooke, D. H. Wahl, and D. P. Philipp. 2007. A review of the effects of catch-andrelease angling on black bass, Micropterus spp.: implications for conservation and management of populations. Fisheries Management and Ecology 14:91-101.

Siepker, M. J., D. H. Wahl, D. P. Philipp, and K. G. Ostrand. 2006. Evidence of reduced reproductive success of nesting largemouth bass sampled with standard electrofishing procedures. North American Journal of Fisheries Management 26:631-635.

Stang, D. L., D. M. Green, R. M. Klindt, T. L. Chiotti, and W. M. Miller. 1996. Black bass movements after release from fishing tournaments in four New York waters. Pages 163-171 in L. E. Miranda and D. R. DeVries, editors. Multidimensional approaches to reservoir fisheries management. American Fisheries Society, Symposium 16, Bethesda, Maryland.

Steinhart, G. B., N. J. Leonard, R. A. Stein, and E. A.
Marschall. 2005. Effects of storms, anglers, and predators on smallmouth bass nest success. Canadian Journal of Fisheries and Aquatic Sciences 62:2649-2660.

Steinhart, G. B., E. A. Marschall, and R. A. Stein. 2004. Round goby predation on smallmouth bass offspring in nests during simulated catch-and-release angling. Transactions of the American Fisheries Society 133:121-131.

Suski, C. D., S. J. Cooke, S. S. Killen, D. H. Wahl, D. P. Philipp, and B. L. Tufts. 2005. Behaviour of walleye (Sander vitreus L.) and largemouth bass (Micropterus salmoides L.) exposed to different wave intensities and boat operating conditions during livewell confinementinsights from videography. Fisheries Management and Ecology 12:19-26.

Suski, C. D., S. S. Killen, S. J. Cooke, J. D. Kieffer, D. P. Philipp, and B. L. Tufts. 2004. Physiological significance of the weigh-in during live-release angling tournaments for largemouth bass. Transactions of the American Fisheries Society 133:1291-1303.

Suski, C. D., S. S. Killen, M. B. Morrissey, S. D. Lund, and B. L. Tufts. 2003a. Physiological changes in largemouth bass caused by live-release angling tournaments in southeastern Ontario. North American Journal of Fisheries Management 23:760-769.

Suski, C. D., F. J. S. Phelan, M. F. Kubacki, and D. P. Philipp. 2002. The use of sanctuaries for protecting nesting black bass from angling. Pages 371-378 in D. P. Philipp and M. S. Ridgway, editors. Black bass: ecology, conservation, and management. American Fisheries Society, Symposium 31, Bethesda, Maryland.

Suski, C. D., and D. P. Philipp. 2004. Factors affecting the vulnerability to angling of nesting male largemouth and smallmouth bass. Transactions of the American Fisheries Society 133:1100-1106.

Suski, C. D., J. H. Svec, J. B. Ludden, F. J. S. Phelan, and D. P. Philipp. 2003b. The effect of catch-and-release angling on the parental care behavior of male smallmouth bass. Transactions of the American Fisheries Society 132:210 218.

Walters, C. J., and S. J. D. Martell. 2004. Fisheries ecology and management. Princeton University Press, Princeton, New Jersey.

Wilde, G. R. 2003. Dispersal of tournament-caught black bass. Fisheries 28(7):10-17.

Wilde, G. R., R. K. Riechers, and R. B. Ditton. 1998. Differences in attitudes, fishing motives, and demographic characteristics between tournament and nontournament black bass anglers in Texas. North American Journal of Fisheries Management 18:422-431. 